\title{
BLDC MOTOROK ELEKTROMÁGNESES SUGÁRZÁSÁNAK MÉRÉSÉRE ALKALMAS LABOR KIALAKÍTÁSA
}

\author{
Bodnár István \\ intézeti tanszékvezetö adjunktus, Miskolci Egyetem, Fizikai és Elektrotechnikai Intézet, \\ Elektrotechnikai és Elektronikai Intézeti Tanszék \\ 3515 Miskolc, Miskolc-Egyetemváros, e-mail: vegybod@uni-miskolc.hu \\ Somogyiné Molnár Judit \\ egyetemi docens, Miskolci Egyetem, Fizikai és Elektrotechnikai Intézet, \\ Elektrotechnikai és Elektronikai Intézeti Tanszék \\ 3515 Miskolc,Miskolc-Egyetemváros, e-mail: gfmj@uni-miskolc.hu \\ Szabó Norbert \\ mesteroktató, Miskolci Egyetem, Fizikai és Elektrotechnikai Intézet, \\ Elektrotechnikai és Elektronikai Intézeti Tanszék \\ 3515 Miskolc, Miskolc-Egyetemváros, e-mail: elkszabo@uni-miskolc.hu \\ Erdősy Dániel \\ egyetemi tanársegéd, Miskolci Egyetem, Fizikai és Elektrotechnikai Intézet, \\ Elektrotechnikai és Elektronikai Intézeti Tanszék \\ 3515 Miskolc, Miskolc-Egyetemváros, e-mail: elkedani@uni-miskolc.hu

\section{Boros Rafael Ruben} \\ tanszéki mérnök, Miskolci Egyetem, Fizikai és Elektrotechnikai Intézet, \\ Elektrotechnikai és Elektronikai Intézeti Tanszék \\ 3515 Miskolc, Miskolc-Egyetemváros, e-mail: elkruben@uni-miskolc.hu
}

\begin{abstract}
Absztrakt
A tanulmány egy BLDC motorok elektromágneses sugárzásának mérésére alkalmas laboratórium és mérökör kialakitásának gyakorlati tapasztalatait mutatja be. Az Elektrotechnikai és Elektronikai Intézeti Tanszék EMC laboratóriuma az 1980-as években került kialakitásra, amely a mai igényeknek nem felel meg, ezért szükségessé vált kismértékü átalakitása. A laborban új földelés lett kialakitva, amely kevésbé vonzza be a külsö zajokat. A próbamérések eredményeire alapozva a háttérzajok kiszürése érdekében a klasszikus botantenna helyett irányitott antenna használata mellet döntöttünk. Az irányított antenna irányfüggö elektromágneses sugárzások pontos mérését teszi lehetövé, így alkalmas gömbi koordinátarendszerben sugárzási karakterisztika felvételére.
\end{abstract}

Kulcsszavak: BLDC motor, EMC labor, elektromágneses kompatibilitás, mérörendszer

\section{Abstract}

This paper presents the practical experiences in creating a laboratory and measuring system suitable for measuring electromagnetic radiation of BLDV motors. The EMC laboratory of the Department of Electrical and Electronic Engineering was established in the 1980s, which does not meet today's needs, therefore a small modification is required. In the lab, new grounding has been created to attract outside noise less. Based on the results of test measurements, we decided to use a directional antenna instead of the classical stick antenna in order to filter background noises. The directional 
antenna enables accurate measurement of direction-dependent electromagnetic radiation, thus it is capable of capturing radiation characteristics in a spherical coordinate system.

Keywords: BLDV motor, EMC laboratory, electromagnetic compatibility, measuring system

\section{Bevezetés}

A kutatómunka célja az volt, hogy egy olyan mérési környezetet alakítsunk ki, amely alkalmas különböző motorikus fogyasztók elektromágneses zajkibocsátásának mérésére. Első sorban kefe nélküli (BLDC- BrushLess Direct Current), úgynevezett elektronikus kommutációjú motorok vizsgálatát tüztük ki célul. Ennek oka, hogy napjainkban egyre jobban terjednek az elektromos autók, amelyek elektromágneses zajkibocsátására szigorúbb feltételeket szabnak meg, mint a hagyományos autókra. Az elektromos autókban nagyobb számban alkalmaznak elektronikát, így nagyobb is annak a veszélye, hogy az egyes alkatrészek, illetve az akkumulátor hütőköri motorok által kisugárzott elektromágneses hullámok zavarják egymást. A zavarhatás eredményeként a különböző érzékelők téves jeleket szolgáltathatnak, így a jármü hibás müködését, leállását, vezetőtől független sebességváltozását is eredményezhetik. Ezek elkerülése érdekében az elektromos autók minden egyes elektromos, illetve elektronikus jármüalkatrészét elektromágneses kompatibilitási (EMC- ElectroMagnetic Compatibility) vizsgálatoknak kell alávetni. Az EMC méréseket EMC kamrában lehet elvégezni, amire szigorú előírásokat tartalmaznak a szabványok $[1,2]$.

\section{Az EMC kamra}

Az elektromágneses kompatibilitási vizsgálatokat olyan kamrában kell elvégezni, amelybe nem szürődik be az azt körülvevő környezet elektromágneses háttérsugárzása. Ez akkor teljesül, ha elektromosan vezető anyagból zárt és földelt ketrecet alakítunk ki. Zárt vezető keretbe se elektromos, se mágneses, se elektromágneses tér, vagy sugárzás nem hatol be. A Miskolci Egyetem Elektrotechnikai és Elektronikai Intézeti Tanszéke rendelkezik egy ilyen kamrával. A kamra az Egyetem egyik épületének pincéjében lett kialakítva, mégpedig úgy, hogy a helyiség falazatában, valamint padló- és födémszerkezetében acélfémháló került bevakolásra. A háló teljesen zár és földeléssel ellátott.

A laboratórium fizikai méretei a következők: 5,14 m szélességü, 7,2 m hosszúságú, így az alapterülete mintegy $37 \mathrm{~m}^{2}$, valamint 2,88 m a belmagassága. Ezek alapján a kamra térfogata megközelítően 106,58 $\mathrm{m}^{3}$. A kamra az 1980-as években került kialakításra, amely akkoriban megfelelt a hatályos szabványoknak.

Mivel a kamrában elsősorban autóipari berendezések mérését végezzük, ezért az „Automotive EMC Testing: CISPR 25, ISO 11452-2 and Equivalent Standards (IN COMPLIANCE, 2016) vonatkozó szabvány elöírásait kell követnünk. Az elöírás a kamrára, a tesztpadra és az alkalmazott mérőmüszerekre is tesz ajánlást. A mérési elrendezés bemutatására az 1 - 3. ábrák szolgálnak, amiket a kamra belső kialakítása, illetve átalakítása során igyekeztünk minél pontosabban figyelembe venni és betartani.

A CISPR 25 kijelenti, hogy a vizsgálati területen az elektromágneses zajszintnek $6 \mathrm{~dB}$-lel alacsonyabbnak kell lennie, mint a tesztelt készülék mérhető legalacsonyabb zajszintje. A CISPR 25-ben található sugárzási határértékek közül néhány $18 \mathrm{~dB}(\mu \mathrm{V} / \mathrm{m})$. Ez azt jelenti, hogy a környezeti zajnak maximum $12 \mathrm{~dB}$-nek $(\mu \mathrm{V} / \mathrm{m})$ kell lennie egy megfelelő környezetben. Az árnyékolt helyiséget tipiku- 
san arra használják, hogy a külső környezet rádiófrekvenciás jeleit kizárják a vizsgálati területről, így a vizsgált berendezés (EUT- Equipment Under Test) továbbra is a sugárzott interferencia domináns forrása marad.

Bár az árnyékolt helyiség túl kicsi ahhoz, hogy rezonancia keletkezzen alacsony frekvenciákon, de a frekvencia növekedésével ennek a valószínűsége megnő. A rezonancia jelentős hibát okozhat a mérésekben.

Ahogyan az 1. ábrán látható, a padon el kell helyezni a legnagyobb EUT-t és az összes olyan kábelt, amely szükséges az áramellátáshoz és az eszközzel történő kommunikációhoz. (Az ábrán a LISN jelölés (Line Impedance Stabilization Network) a stabilizált hálózati vonalimpedanciát jelenti.) A kábeleket egy vezetőcsatornába teszik, amely a pad elülső éle mentén helyezkedik el. Maga a kábelköteg az EUT egyik jelentős eleme, és a mérőantenna által vizsgált fö komponens, mivel az alacsonyabb frekvenciákon (amelyeknél a vizsgált BLDC motor elektromágnesesen kis sugárzással rendelkezik) a fö forrást az eszközt tápláló kábelek által sugárzott mező adja. Ugyanezt az eljárást alkalmazzák a MIL STD 461 [3] és az ISO 11452 [4] szabványban, és amint az ábrán látható, egy vonalimpedanciastabilizáló hálózatot használnak, hogy meghatározott impedanciát biztosítsanak a készülék áramellátására.

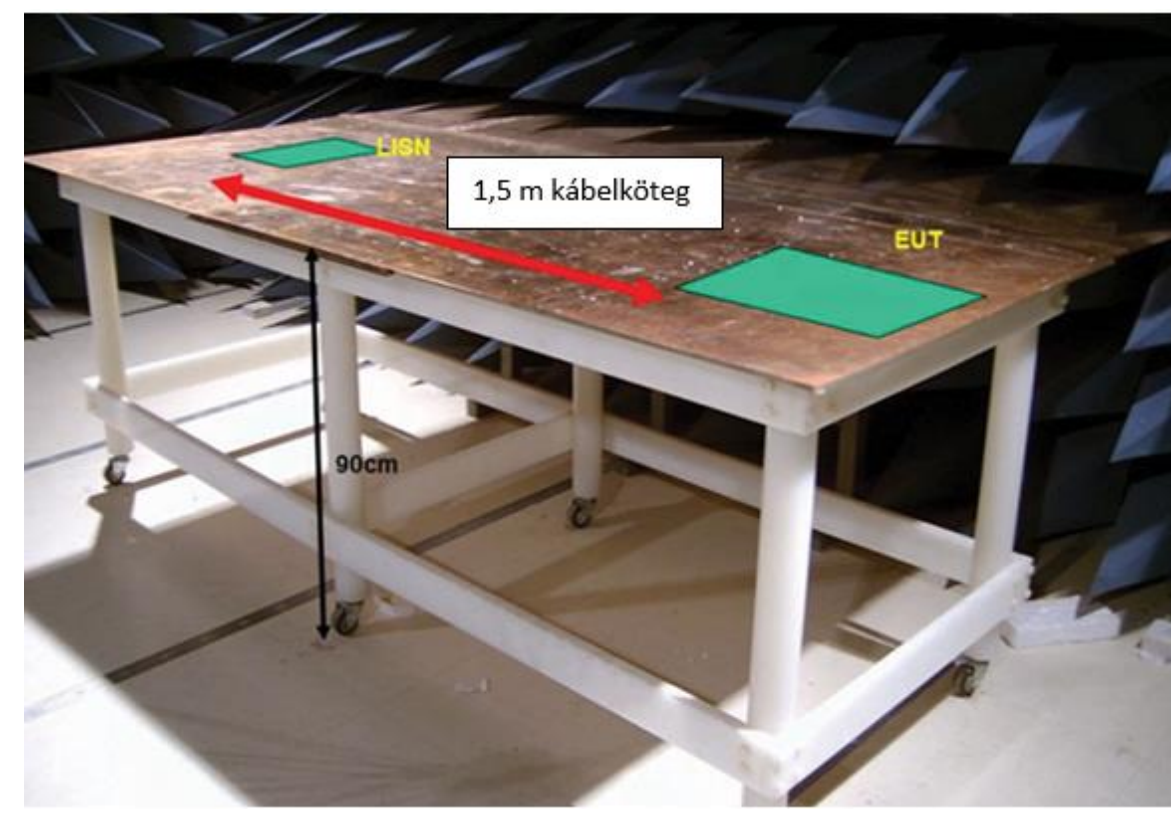

1. ábra. CISPR 25 alapján EMC méréshez használható elrendezés.

A 2. ábra azt mutatja, hogyan határozható meg a pad mérete. A pad alaplemezének egészen az árnyékolásig kell terjednie, és a legtöbb esetben az árnyékolt helyiség falához kell igazítani. A szabvány azonban lehetôvé teszi, hogy a pad alternatívaként a padlóhoz legyen földelve.

A CISPR 25-ben meghatározottak szerint a sugárzott kibocsátás referencia alapterületének (padnak) minimális szélessége $1.000 \mathrm{~mm}$, hossza pedig legalább $2.000 \mathrm{~mm}$, vagy a teljes EUT plusz 200 $\mathrm{mm}$, amelyik nagyobb a kettő közül. 
A megfelelő kamra minimális méreteit elsősorban a próbapad méretei határozzák meg. A kamra falainak és mennyezetének $60 \mathrm{~cm}$ mélységü hibrid abszorber használatával a 2. ábrán láthatjuk, hogy a kamra szélességét az abszorbens anyag hossza határozza meg. A pad és az abszorbeáló anyag csúcsai között egy méternek kell lennie. Azoknál a kamráknál is, amelyek szintén használatosak az elektromos motor vizsgálatához, a motor is része az EUT-nek. Bizonyos esetekben a motort mechanikai okokból a próbapad melletti külön szerkezettel támogatják. Ebben az esetben még mindig hozzá kell kapcsolódnia a talaj síkjához, így effektív lesz az alaplap padjának meghosszabbítása és a szabványban meghatározott legkisebb távolságoknak megfelelően.

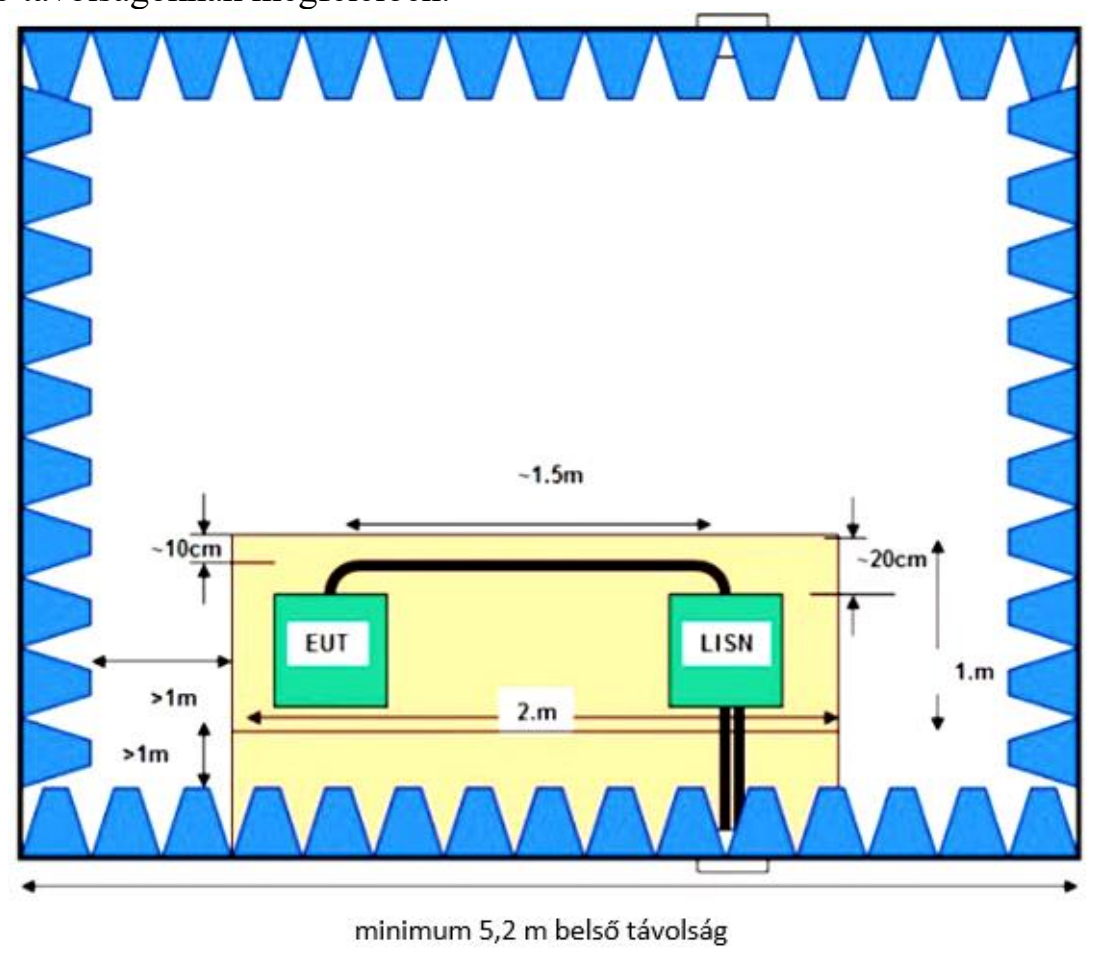

2. ábra. CISPR 25 alapján a tesztpad mérete.

A kamra magasságához és hosszához a CISPR 25 meghatározza a szükséges minimális távolságokat:

- az első és a legkritikusabb a vizsgálati távolság, ahol az EMC zajkibocsátást legalább $1 \mathrm{~m}$ távolságra kell mérni a kábelkötegtől az antennához képest;

- a másik szabály szerint az antenna egyetlen része sem lehet közelebb 1 m-nél az abszorbeáló anyag csúcsától.

Ezek a szabályok és az ajánlott antennák határozzák meg a kamra hosszát és magasságát. A kábelköteg $1 \mathrm{~m}$-es távolságát az egypólusú botantenna és a bikonikus antenna tartó elemének tengelyétől mérik. A log periodikus dipólusantenna (LPDA) esetében a távolságot az antenna csúcsától mérjük. Végül a kürt antennáknál a távolságot az antennától, vagy az apertúra síkjától mérjük. A leghosszabb 
antenna az LPDA. A 200 MHz-től 2,5 GHz-es tartományba eső tipikus LPDA-k teljes hossza körülbelül $1 \mathrm{~m}$.

A kamra magasságát a leghosszabb antenna adja. A leghosszabb antenna rendszerint az aktív monopol rúdja. A monopolt rendkívül kis elektromosan földelő ellenállással rendelkező síklappal használják. A szabvány szerint a monopol rúdja kb. $80 \mathrm{~cm}$ hosszú, és úgy van elhelyezve, hogy az alaplap síkja ugyanolyan szinten legyen, mint a padé, amint a 3. ábrán látható, névlegesen $90 \mathrm{~cm}$ magas. $\mathrm{Az}$ antenna és az abszorber csúcsa közötti szétválasztásra szolgáló 1 méteres szabály ismét meghatározza a kamra méretét, amit szintén a 3. ábra mutat.

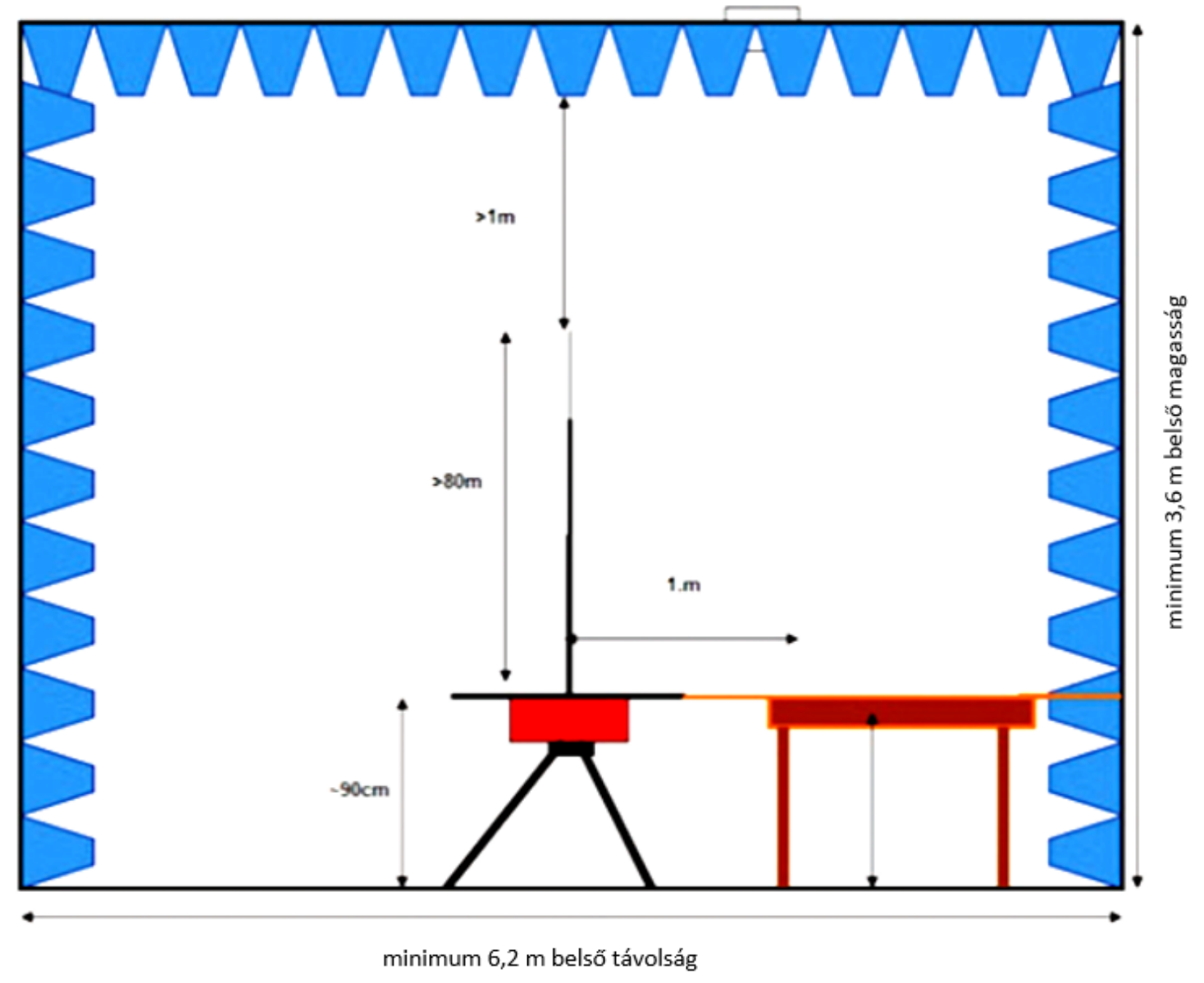

3. ábra. CISPR 25 alapján EMC méréshez használható elrendezés.

Az Elektrotechnikai és Elektronikai Intézeti Tanszék EMC kamrája sajnos nem tartalmaz polisztirol abszorbereket, de a szabvány által elöírt antenna magasságot és hosszt, valamint a mennyezettöl és a mérőasztaltól való távolságot biztosítani tudja.

A kamra nagy hibája, hogy a váltakozóáramú és az egyenáramú tápellátása, valamint a világítás elhelyezése a zárt vezető kereten belül található. Manapság ugyan ez már nem elönyös a vizsgálatok 
elvégzése szempontjából, mert azok antennaként viselkednek és zavarhatásokat húznak be a laboratóriumba, azonban megfelelően kialakított mérőrendszer esetében kompenzálható azok negatív hatása.

Mindezeken kívül a laboratóriumban található védőföldelés sem kielégítő, mert zavarhatás mérhető rajta, ezért indokolttá vált a laboratórium átalakítása saját, helyi földelés kialakítása. A laboratórium padlózatában $80 \mathrm{~cm}$ mélységig leérő földelő szondát helyeztünk el. Az első $35 \mathrm{~cm}$ mélységig beton alapzatot, az azt követő $45 \mathrm{~cm}$ vastagságú rétegben agyagos talajt találtunk. A vezetöképesség növelése érdekében minden mérés elött a földelőszonda és a beton körüli hézag vízzel kerül feltöltésre. A földelő szonda elhelyezése a 4. ábrán látható.

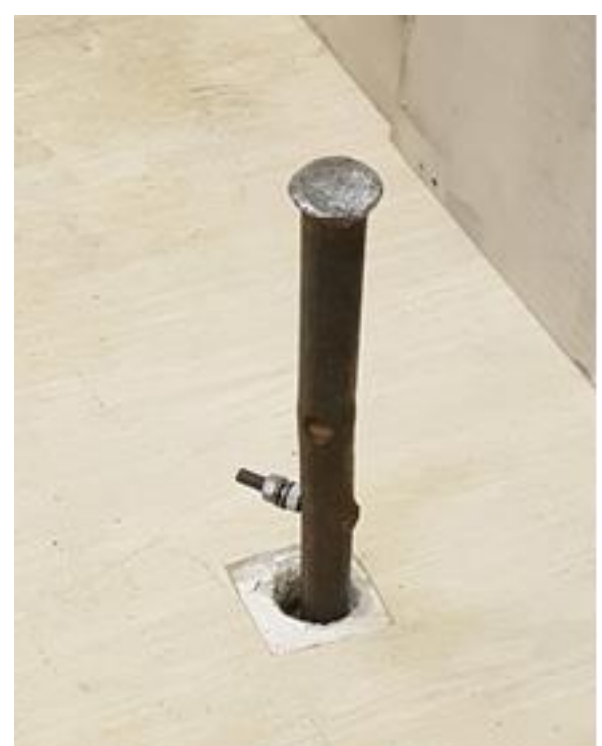

\section{4. ábra. Helyi földelés kialakitása földelöszonda alkalmazásával.}

Az EMC laborban lévő földelés és az újonnan kialakított közvetlen földelés ellenállását egy MACROTEST 5035-ös készülékkel mértük meg. Eredő földelési ellenállást mértünk $15 \mathrm{~mA}$ árammal, illetve $50 \mathrm{~V}$ érintésvédelmi törpefeszültséggel, valamint hálózati impedanciát és a nulla - védőföld közötti ellenállást. A mérési eredmények az 5. ábrán láthatók. Hurokimpedancia mérésnél a fázis és nulla vezető között $0,42 \Omega$-ot, a fázis és a hálózati védőföld között $0,54 \Omega$-ot, míg a fázis és az újonnan telepített védőföld között 1,02 $\Omega$-ot, mértünk. Az eredő földelési ellenállás mérésénél mind a hálózati, mind az újonnan kialakított védőföldelés esetében $1 \Omega$-ot kaptunk, azonban ezeknek a mérésnek $1 \Omega$ a felbontása, tehát nincs különbség a többi mérés eredményeivel szemben. Ennél pontosabb képet csak további földelő szondák elhelyezésével lehetne kapni, azonban a teljes betonpadlózat miatt ez nem megvalósítható. Minden érték kisebb, mint $3 \Omega$, tehát a földelés megfelel az elvárásoknak! 


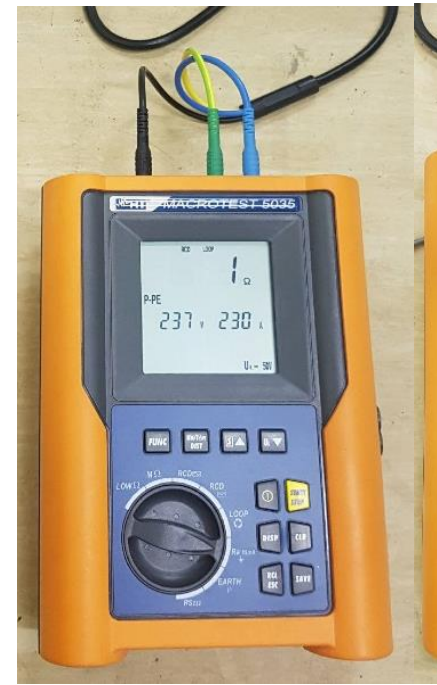

a)

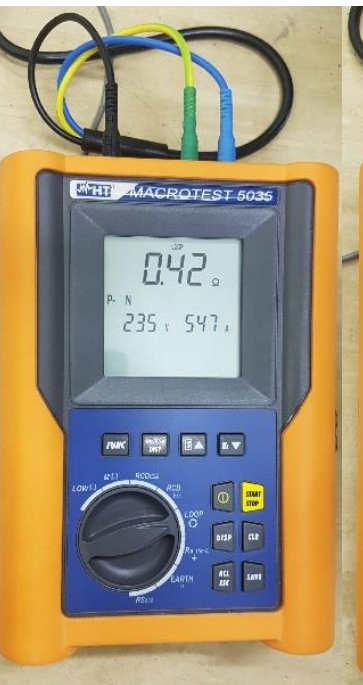

b)

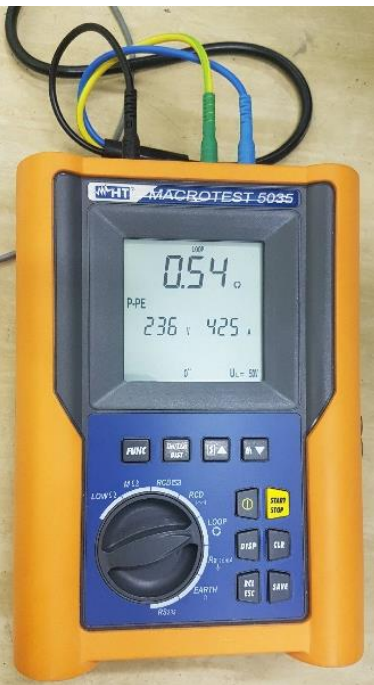

c)

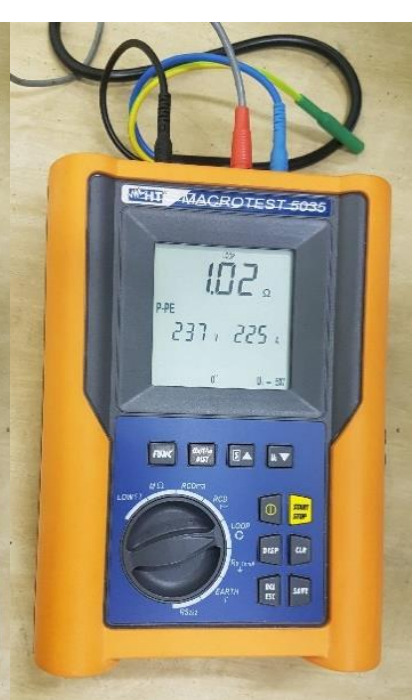

d)

5. ábra. Eredö földelési ellenállás és hurokimpedancia mérési eredmények.

\section{a) Eredö földelési ellenállás mérése}

b) Hurokimpedancia mérése, fázis és nulla vezetö közötti ellenállás

c) Hurokimpedancia mérése, fázis és a hálózati védöföld közötti ellenállás

d) Hurokimpedancia mérése, fázis és a kialakitott védöföld közötti ellenállás

Ugyan az újonnan kialakított védőföldelés alkalmazása esetében nagyobb hurokimpedancia tapasztalható, mint a laboratóriumban megtalálható hálózati védőföld és a fázisvezető között, azonban egy lényeges szempontot nem szabad figyelmen kívül hagyni, ez pedig a védővezetőn lévő háttérzaj mértéke. A 6. ábra szemlélteti a hálózati védőföldelésen tapasztalható háttérzajt. Az újonnan kialakított földelésen e háttérzaj nem jelentkezett. Mindezek alapján elmondható, hogy az újonnan kialakított földelés pontosabb mérések elvégzését teszi lehetővé a háttérzajok e részének kiszürése révén.

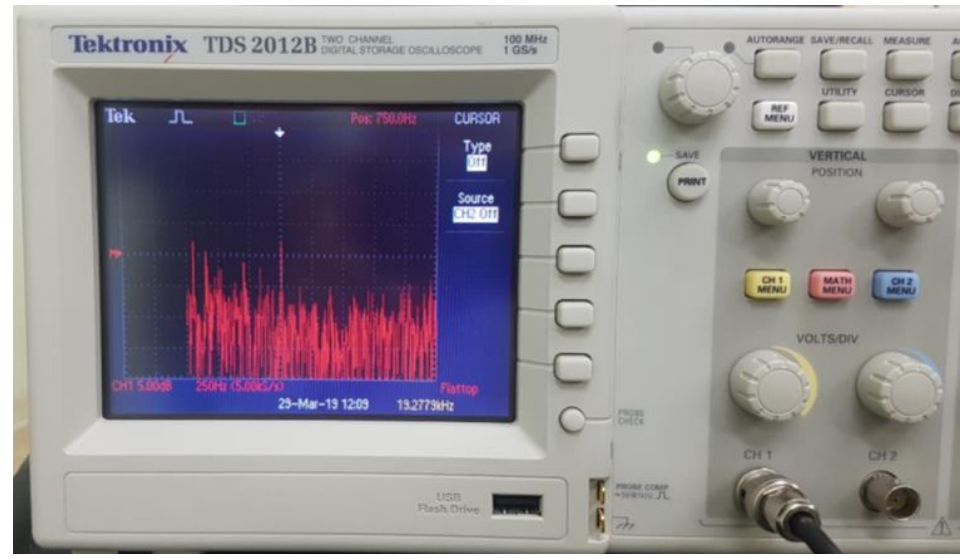

6. ábra. A hálózati védöföldelésen tapasztalható zaj. 


\section{A mérőkör kialakítása}

A mérőrendszer kezdeti kialakítása PMM 7000 előminősítő műszerhez kapcsolt botantennát, PXI mérőszámítógépet, Tetronix TDS 2012B típusú oszcilloszkópot és Chauvin Arnoux C.A 8230 típusú hordozható teljesítményanalizátort tartalmazott. A 7. ábrán a PMM 7000 előminősítő müszer látható.

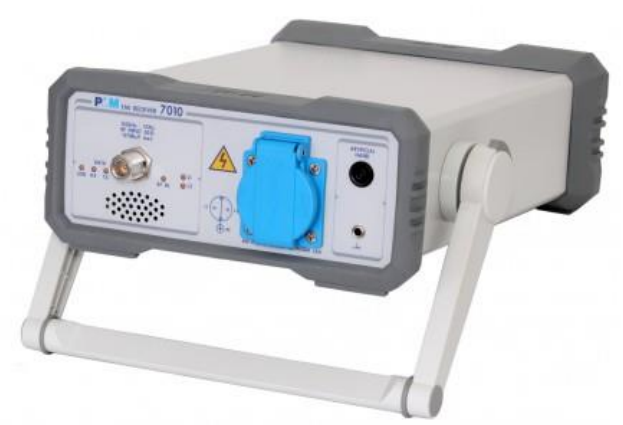

7. ábra. PMM 7000 .

Az első méréseknél rá kellett jönnünk, hogy ez a mérési összeállítás nem felel meg az elvárásainknak, így újra kellett gondolni a mérőrendszert. A laborba beszürődő külső jelek befolyásolták a mérést, így nem lehetett egyértelmüen elkülöníteni a vizsgálat tárgyát képező motor által keltett és a kamrába beszürődő elektromágneses zajokat. Emiatt olyan mérörendszert kellett kialakítani, amely alkalmas a hibák kompenzálására. Végül az említett előminősítő müszer helyett egy Rohde \& Schwarz müszerrel és egy irányított antennával terveztük az új mérörendszert kialakítani (8. ábra).

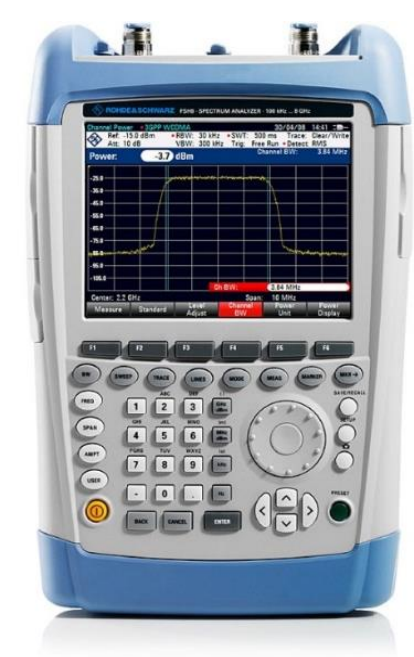

8. ábra. Rohde \& Schwarz FSH8.

A műszer egy hordozható spektrum analizátor, amely a megfelelő antennával használható az általunk vizsgált frekvenciatartomány mérésére is. Ehhez egy HE300-as irányított antenna áll rendelkezésünkre, amely $9 \mathrm{kHz}$ és $20 \mathrm{MHz}$ közötti frekvenciákra van fejlesztve (9. ábra). Ezt az antennát egy 
egyszerü kamera állványra lehet rögzíteni, ezt kihasználva biztosítottuk mi is az eszköz stabilitását és a precíz elhelyezését a mérések közben.

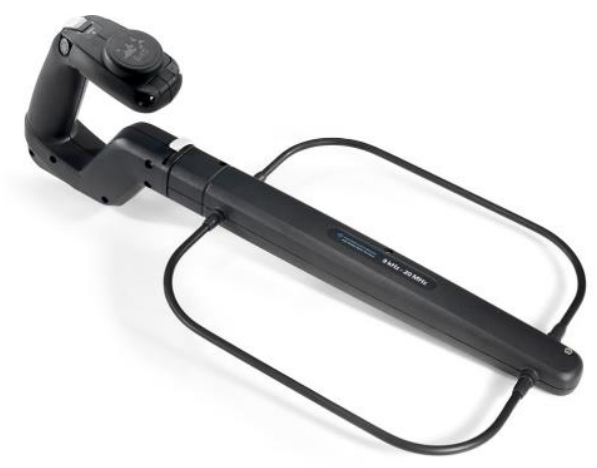

\section{9. ábra. HE300-as irányított antenna.}

Az FSH8 ethernet és USB kábellel is csatlakoztatható számítógéphez. Az egyszerüség miatt mi USB kábelt használtunk erre a célra. A megfelelő eszközillesztő és szoftver feltelepítése után a gyári szoftver többféleképpen képes kiolvasni a mért értékeket az eszközből. A mérésnél jelen lévő számítógépre feltelepítettük a szükséges szoftvereket, valamint megoldást találtunk arra, hogy hogyan tudjuk hatékonyan kezelni a mért és mentett értékeket. A szoftverbe korábbi adatokat is vissza lehet tölteni, így ugyanolyan grafikonokon lehet dolgozni, mint mérés közben (10. ábra). A grafikonok adatait excel formájában le lehet menteni, így numerikusan is feldolgozható adatokat kapunk.

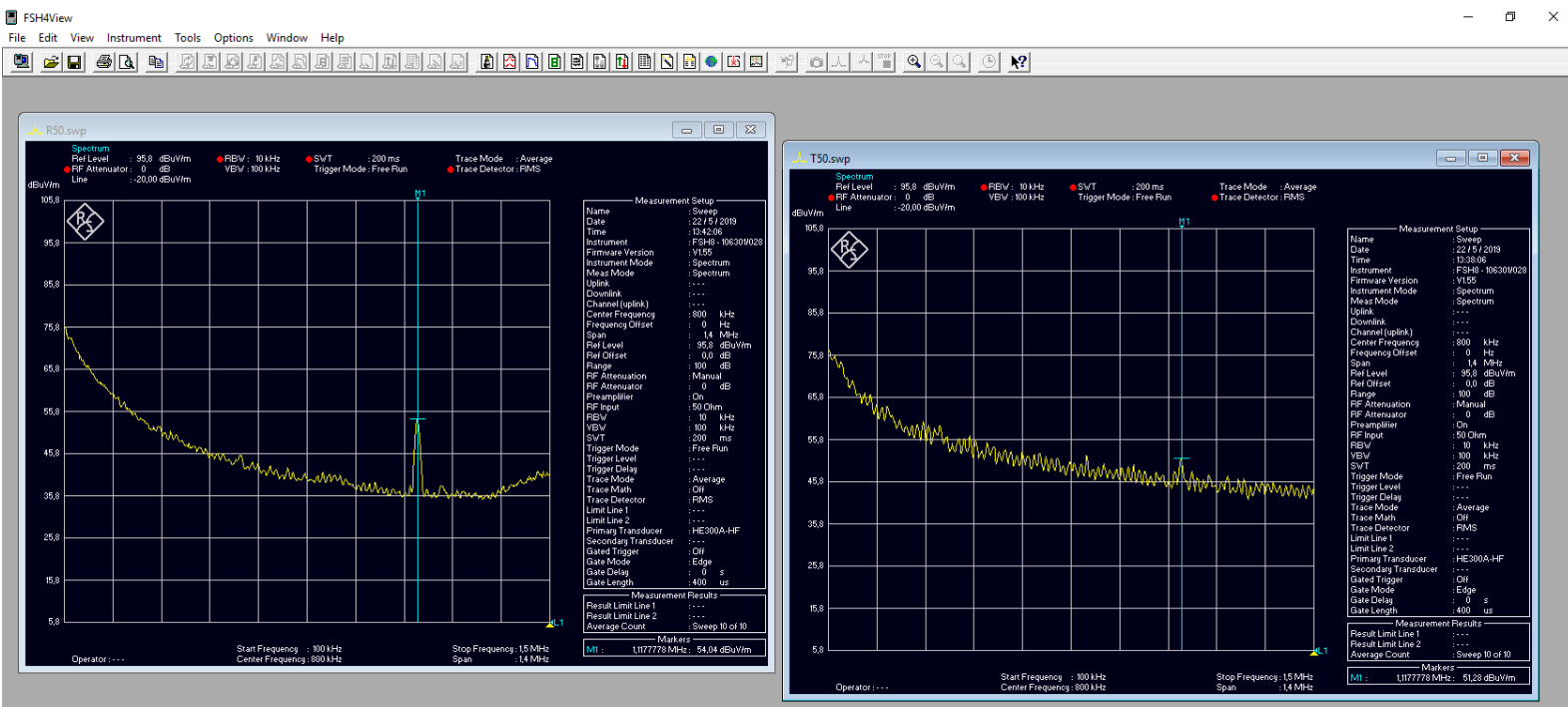

10. ábra. Mért adatok visszatöltése a programba. 


\section{4. Összefoglalás}

Összességében elmondható, hogy a kitüzött célokat sikerült teljesítenünk, hiszen a meglévő EMC kamrát sikerült úgy átalakítani, illetve abban olyan mérőrendszert kialakítani, amely alkalmas BLDC motorok elektromágneses sugárzásának mérésére, összehasonlító vizsgálatok és elemzések készítésére, valamint a mérésekből származó információkból továbbfejlesztési javaslatok tételére.

\section{Köszönetnyilvánítás}

A cikkben ismertetett kutatómunka az EFOP-3.6.1-16-2016-00011 jelü „Fiatalodó és Megújuló Egyetem - Innovatív Tudásváros - a Miskolci Egyetem intelligens szakosodást szolgáló intézményi fejlesztése" projekt részeként - a Széchenyi 2020 keretében - az Európai Unió támogatásával, az Európai Szociális Alap társfinanszírozásával valósul meg.

\section{Irodalom}

[1] Varga, A.: Grundlage des Elektrosmogs in Bildern. Verlag Umwelt + Medizin, Heidelberg, 2002. p. 155.

[2] Rejtö, F.: EMC alapok. Magyar Elektrotechnikai Egyesület, Budapest, 2006. p. 260.

[3] EMCO: Antenna Catalog. Austin, Texas, USA, 2000.

[4] Szücs, L.: RF zavarkibocsátás és zavarérzékenység mérés. Mérési segédlet, Budapesti Müszaki és Gazdaságtudományi Egyetem, 2002. p. 13. 